Alex Murray and Jessica Whyte. The Agamben Dictionary. Edinburgh: Edinburgh University Press, 2011. 219p. alk. paper, $\$ 40.00$ (ISBN 9780748640584). LCCN 2011-431345.

Born in 1942, Giorgio Agamben is considered a leading figure in philosophy and political theory, one who is known for challenging the Western political tradition. After completing his studies in law and philosophy, and earning his doctorate, he taught at various universities in Europe and was a visiting professor at various universities in the United States. Agamben is no stranger to controversy. His entry to the United States was accompanied by a controversy upon his refusal to submit to fingerprinting as requested by the U.S. Immigration Department following the attacks on September 11, 2001. In no uncertain terms, he stated his objection to this "biopolitical tattooing" in an article that appeared in Le Monde: "I have no intention of submitting myself to such procedures and that's why I didn't wait to cancel the course I was supposed to teach at New York University in March" (Jan. 10, 2004). His radical critique continues to redefine and fashion concepts and terminologies in areas such as ethics, law, epistemology, language, and logic, among others. To this end, Murray and Whyte bring together a collection of essays written by renowned and emerging experts to illustrate Agamben's influence in a broad spectrum of disciplines.

Murray and Whyte are no strangers to Agamben. Alex Murray began his appointment as English Literature Lecturer in 2007 at the University of Exeter's English Department. He is extensively published in literary studies and critical theories and has written several monographs, articles, book chapters, and reviews. The Encyclopedia of Literary and Cultural Theory (Oxford, 2011) recently published Murray's entry on Agamben. In addition, he is coeditor of The Work of Giorgio Agamben: Law, Life, Literature (Edinburgh Press, 2008), an indepth treatment of the philosopher's work. Later, in 2009, he wrote "Law and Thought: on the Work of Giorgio Agamben" (Law $\mathcal{E}$
Critique 20:3), and, in 2010, Murray summarized his key ideas in Giorgio Agamben (Critical Thinkers Series, Routledge). Currently, Murray is cofounder of Parrhesia: A Journal of Critical Philosophy (www. parrhesiajournal.org). His collaborator, Jessica Whyte, is a lecturer in cultural and social analysis at the University of Western Sydney, Australia. She completed her doctorate on the political thought of Giorgio Agamben in 2010 and published widely on contemporary continental philosophy, including Foucault and Ranciere, and critical and legal theories. In addition to the reviewed publication, she coedited the Theory and Event Symposium "Form of Life: Giorgio Agamben, Ontology, Politics" (2010), as well as the Australian Feminist Law Journal special edition "Law, Crisis, Revolution" (2010).

Until now, scholarly publications focused on the philosopher's individual works. This is the first attempt to illustrate the complexity of his body of work as a whole. Carefully researched and assembled, The Agamben Dictionary is a collection of short essays that introduce key terms and concepts spanning the gambit from Abandonment to Zoē. Each essay includes cross-references to other terms, in bold type. The dictionary concludes with a comprehensive biography of Agamben's works to date, cited works, further readings, and notes on contributors. The dictionary is a valuable reference for researchers interested not only in Agamben's work but also in understanding his place in contemporary philosophy and political critique as overall disciplines. Ethan Pullman, Carnegie Mellon University.

\section{Digital Media: Technological and Social Challenges of the Interactive World.}

Eds. Megan A. Winger and William Aspray. Lanham, Md.: Scarecrow Press, 2011. 237p. alk. paper, \$55 (ISBN 9780810881969). LC2011-016306.

Compiled by scholars from industry and academia in fields ranging from the arts and humanities to information studies, Digital Media explores, from multiple 
perspectives, the "history, collection development, preservation, and ontological challenges of digital media." This anthology is based on research presented at an invitation-only workshop on digital media, hosted by the School of Information at the University of Texas at Austin in February 2009. With the evolution of digital media over the past three decades, new challenges such as the preservation of information regarding virtual worlds and online games have emerged. The authors posit that while preserving digital media is vital, the preservation of information about digital objects, including administrative, descriptive, and cultural data, is equally important.

The book is broken into four parts, with each focused on an aspect of digital media. The first part discusses the importance of preserving digital objects (in particular, virtual worlds like The Sims Online and others due to the historical value of these digital artifacts). Other items examined in this section include the necessity of new and variable archival models for preserving, documenting, and accessing digital objects, as opposed to models used for traditional materials. Examples are also given where piracy of copyrighted material played a positive role in preservation.

In the second part, the authors describe the challenges of creating, compiling, and preserving authoritative metadata about a digital object. This section describes the retrieval concerns of born-digital items and the need for dynamic classification standards. Such standards are integral to innovative design of new media by balancing the goals of arrangement with user information needs and continue to evolve due to "the shifting nature of the field."

The third part addresses the humancentered and interactive relationship with digital media ranging from applications for mobile devices to blogs. The section begins with the proposal of using a "personal theory" writing method in the realm of the humanities discipline. This method is defined as a "personalized rendering of theoretical concepts" and blends first-person narratives with digi- tal media. The author proposes that this style, while analogous to the first-person storytelling blended with philosophical writings by authors such as Thoreau and St. Augustine, is ideal for use with digital media. This section also highlights the issue of the "digital media divide" by analyzing two reports concerning the digital divide, one by Henry Jenkins (2006) and the other by Larry Snyder (1999). The author suggests that the debate about the digital divide must focus on the "skillful and meaningful use of digital resources" rather than a debate about digital access.

The final part examines the dynamic relationship between digital media and culture over time. Topics include the role and evolution of digital media in the creation, dissemination, and reception of artistic works, in contrast to traditional artistic media. The impact of music technologies for both the artist and audience from the late 1950s to the present is discussed. The section closes with a discussion of the role of digital humanities, a budding field "grounded in the theories and methods of humanist scholarship." The interplay between digital media and technology innovations are evaluated regarding the present and future cultural implications.

This work offers varied perspectives and interesting theoretical ideas regarding the emerging challenges of digital media. The book as a whole will be of interest to scholars of library and information science, though specific chapters could also be of interest to those in other fields such as communications, media studies, and fine arts. A definite strength of the book is the diversity of backgrounds represented by the authors and the unique topics presented. Unfortunately, in a few instances the wide range of topics covered within particular parts of the book disrupt the transition between chapters. Another weakness is the scant coverage of proposed solutions and best practices to the inherent challenges of digital media. Practitioners seeking a plethora of pragmatic ideas will be disappointed. However, readers seeking descriptive information about some of the inherent 
challenges of preserving digital objects, metadata about these objects, user experiences with these digital objects, and information about the dynamic relationship between these technologies and culture, will find this book useful. - Anders Selhorst, Guilford Technical Community College.

Lesley S. J. Farmer. Instructional Design for Librarians and Information Professionals. New York: Neal-Schuman, 2011. 229p. alk. paper, $\$ 80.00$ (ISBN 9781555707361). LC 2011-31233.

Intended as a handbook for working librarians as well as a textbook for library and information science courses, this book aims to improve librarians' instruction by making the planning process more systematic. Farmer follows Robert A. Reiser's and John V. Dempsey's 2007 definition of instructional design as an iterative process that moves reflectively through the stages of analysis, design, development, implementation, and evaluation. Early in the book, Farmer observes that the instructional design process has several characteristics that makes it well suited for the kinds of instruction engaged in by librarians. Instructional design is learner centered (for individual learners as well as groups); goal oriented (both learners and instructors know the goals); performance focused (learners are asked to demonstrate their new knowledge or

\section{Index to advertisers}

AIAA

Annual Reviews

Bowker/RCL

CHOICE Reviews Online

Digital Libr. Sys. Grp. cvr 4, 259,261 EBSCO

ISTE cover 2

Modern Language Assoc. cover 3 Peter Lang Publishing 232 Peterson Institute 205 Philosophy Documentation Ctr. 216 Society for Industrial \&

Applied Mathematics 208-209 Society for American Archivists 302 skills); data driven (data is generated by both teachers and learners, throughout the process); and self-correcting (the instructor analyzes the data collected and makes adjustments to each step in the process).

Farmer has strong credentials in instruction. Her PhD is in adult education, she has worked as a K-12 library media specialist and currently teaches in and coordinates the librarianship program at California State University, Long Beach. Her publications include more than twenty books and numerous articles. She received ALA's Beta Phi Mu Award in 2011 for distinguished contributions to education in librarianship.

In each of the book's nine chapters, Farmer's exposition takes a broad view of instructional design, while her varied examples link the material to libraries. Chapter Two, "Instructional Design Overview," illustrates this approach. Farmer introduces several instructional design models; each either is broad enough to apply to libraries or fits particular needs that libraries have. Within this survey of models, she provides a succinct, highly useful case study that illustrates the ADDIE (Analysis, Design, Development, Implementation, and Evaluation) model's application to a school library setting. The case study's steps are easily transferable to other types of libraries. She also introduces BLAAM (Blended Librarians Adapted ADDIE Model), which better fits the smaller scale of most instruction in academic libraries. Rapid Prototyping (discussed further in the chapter on design content decisions) is a technology design process that academic librarians might find useful for designing online tutorials. Farmer suggests that, for efficiency, libraries adopt one model for all their instructional design.

Subsequent chapters (learners in instructional design; preplanning; design content decisions; instructional delivery; technology; instructional systems; and management issues) follow a common format. Farmer first identifies core features and issues that must be considered for a given stage or aspect of instruction 